\title{
SEMINAR TENTANG PELEMBAB KULIT WAJAH DARI EKSTRAK DAUN NANGKA (ATROCARPUS HETEROPYLLUS LAM.)
}

\author{
Tri Nova Lovena ${ }^{1 *}$, Aminah², Nur Ulina M. Br. Turnip ${ }^{2}$ \\ ${ }^{1}$ Program Studi Profesi Apoteker, Institut Kesehatan Medistra Lubuk Pakam \\ ${ }^{2}$ Program Studi Farmasi, Institut Kesehatan Medistra Lubuk Pakam \\ Jln. Sudirman No.38 Lubuk Pakam, Kabupaten Deli Serdang, \\ Sumatera Utara - Indonesia \\ *email korespondensi author: lovenanovatri@gmail.com
}

DOI $10.35451 /$ jpk.v1i1.740

\begin{abstract}
Abstrak
Indonesia menduduki keaneka ragaman hayati tertinggi kedua didunia setelah brazil dengan 7000 jenis tanaman berkhasiat sebagai obat. Tanaman obat sudah sangat lama digunakan sebagai salah satu alternatif pengobatan kesehatan. Salah satu tanaman Indonesia yang berpotensi menghasilkan antioksidan alami adalah daun nangka yang mengandung flavonoid, saponin, tannin. Flavonoid sebagai antibakteri bekerja dalam mendenaturasi protein sel bakteri dan merusak membran sel. Tujuan: membuat sediaan krim masker ekstrak daun nangka. Daun nangka berguna dalam pengobatan demam, bisul, penyakit kulit, antidiare, analgesik dan imunomodulator. Daun nangka diketahui mengandung flavonoid, saponin dan tanin yang berperan sebagai senyawa antibakteri. Metode seminar dilakukan secara sosialisasi dengan melakukan zoom dengan peserta sebelum dilakukan pengujian sediaan, adapun tahapan metode pada seminar ini adalah tahapan penyiapan dan evaluasi sediaan. Sosialisasi mengenai pelembab kulit dilakukan secara langsung terhadap peserta melalui kegiatan seminar. Sosialisasi ini diharapkan dapat membuka dan menambah wawasan para peserta. Ekstrak daun nangka yang diperoleh melalui metode maserasi diidentifikasi metabolit sekundernya melalui skrining fitokimia. Ekstrak kemudian akan diformulasikan menjadi sediaan masker yang akan melembabkan kulit. Hasil ekstrak kental diperoleh zat aktif dengan konsentrasi 5\% dan 10\%. Uji sediaan uji organoleptis, meliputi pemeriksaan homogenitas, sediaan ph dan kelembaban kulit. Uji homogenitas menunjukkan bahwa sediaan krim masker yang dihasilkan homogen, rentang $\mathrm{pH}$ 6-7 dan uji kelembaban dengan konsentrasi 5\% diperoleh nilai rata-rata dan dapat melembabkan kulit dan konsentrasi $10 \%$ diperoleh nilai rata-rata $59,46 \%$ dapat melembabkan kulit. Ekstrak daun nangka dapat diformulasikan dalam sediaan krim masker dan sediaan krim masker ekstrak daun nangka dapat melembabkan kulit.
\end{abstract}

Kata Kunci: Ekstrak daun nangka, Sediaan masker, Pelembab.

\begin{abstract}
Indonesia occupies the second highest biodiversity in the world after Brazil with 7000 species of medicinal plants. Medicinal plants have long been used as an alternative health treatment. One of the Indonesian plants that have the potential to produce natural antioxidants is jackfruit leaves which contain flavonoids, saponins, and tannins. Flavonoids as antibacterial work in denaturing bacterial cell proteins and damaging cell membranes. Purpose: to make a mask preparation of jackfruit leaf extract. Jackfruit leaves are useful in the treatment of fever, ulcers, skin diseases, antidiarrheal, analgesic and immunomodulatory. Jackfruit leaves are known to contain
\end{abstract}


Received: 14 June 2021 :: Accepted: 21 June 2021 :: Published: 30 June 2021

flavonoids, saponins and tannins that act as antibacterial compounds. The seminar method is carried out through socialization by zooming in with the participants before testing the preparations, while the method stages in this seminar are the preparation and evaluation stages of the preparations. Dissemination of skin moisturizers is carried out directly to participants through seminar activities. This socialization is expected to open and broaden the participants' knowledge. Jackfruit leaf extract obtained by maceration method identified its secondary metabolites through phytochemical screening. The extract will then be formulated into a mask preparation that will moisturize the skin. The results of the thick extract obtained active substances with concentrations of $5 \%$ and $10 \%$. Organoleptic test preparations include examination of homogeneity, $\mathrm{pH}$ and skin moisture. The homogeneity test showed that the mask cream preparations were homogeneous, with a $\mathrm{pH}$ range of 6-7 and a moisture test with a concentration of $5 \%$ obtained an average value and could moisturize the skin and a concentration of $10 \%$ obtained an average value of $59.46 \%$ which could moisturize the skin. Jackfruit leaf extract can be formulated in mask cream preparations and mask cream preparations, jackfruit leaf extract can moisturize the skin.

Keywords: Jacfruid leaf extract, mask cream preparations, moisturizer

\section{Pendahuluan}

Indonesia menduduki keaneka ragaman hayati tertinggi kedua didunia setelah brazil dengan 7000 jenis tanaman berkhasiat sebagai obat. Tanaman obat sudah sangat lama digunakan sebagai salah satu alternatif pengobatan kesehatan (Hemani, 2011).

Proses identifikasi herbal yang tidak tepat, terdapat mikroorganisme pada bahan, serta residu pestisida akibat proses pembersihan yang tidak tepat dapat menyebabkan efek samping. Oleh sebab itu, perlu dilakukan pengujian obat herbal agar menghasilkan simplisia (Andhi, 2020).

Tanaman yang tinggi antioksidan salah satunya adalah daun nangka, selain itu dapat mengangkat sel kulit mati. Daun nangka mengandung saponin, flavonoid, dan tanin. Kandungan saponin yang tinggi terdapat pada buahnya (Diah, 2016).

Kulit wajah yang cantik, segar dan mulus berseri adalah impian kaum wanita. Oleh sebab itu, berbagai cara dilakukan untuk mendapatkan kulit wajah yang cantik dan mulus (Sukmawati, 2013).
Perawatan dilakukan dengan menggunakan kosmetik perawatan, misalnya milk cleanser, face peeling cream, dan masker wajah (Septiani, 2012). Perawatan ini dilakukan secara teratur, jika tidak teratur akan menimbulkan efek negatif seperti ditumbuhin jerawat, figmentasi dan kelainan yang lain. Oleh sebab itu perawatan dilakukan secara bertahap (Maharani, 2015).

Melembabkan, menghaluskan kulit serta memberi nutrisi pada kulit merupakan fungsi dari penggunaan masker. Kandungan flavonoid, saponin, dan tanin yang terdapat pada daun nangka berkhasiat sebagai antioksidan yang dapat menghaluskan kulit, melembabkan kulit, menjaga kelembutan kulit agar kulit terlihat muda dan segar (Wibisana, 2013).

\section{Metode}

\section{Bahan}

Bahan yang digunakan adalah sampel daun nangka, alat tulis kantor (ATK) dan materi sosialisasi.

\section{Peralatan}


Received: 14 June 2021 :: Accepted: 21 June 2021 :: Published: 30 June 2021

Alat peraga seperti alat gelas yang digunakan ketika melaksanakan ekstraksi , instrumen seminaryang disuguhkan melalui aplikasi virtual zoom. Gambar sosialisasi dapat dilihat

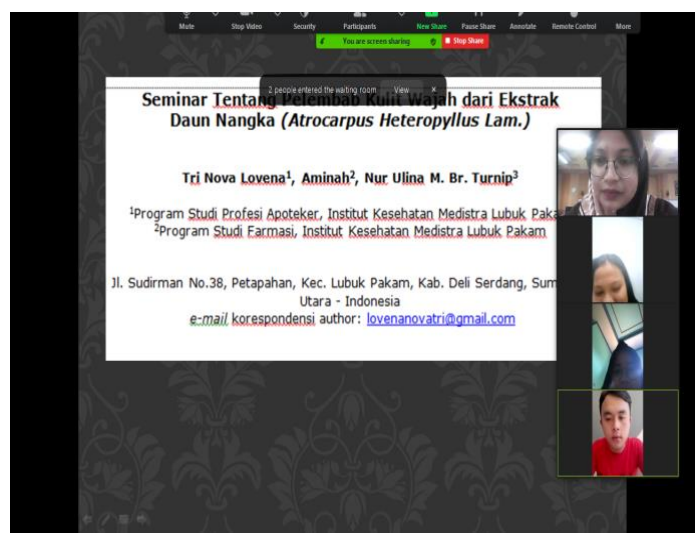

pada gambar 1 .

Gambar 1. Gambar tentang seminar pelembab kulit wajah dari ekstrak daun nangka

Prosedur Mempersiapkan materi sosialisasi yang digunakan pada kegiatan pengabdian ini adalah sebagai berikut:

\section{a. Tahap Pelaksanaan kegiatan}

Sosialisasi mengenai pelembab kulit dilakukan secara langsung terhadap peserta melalui kegiatan seminar. Sosialisasi ini diharapkan dapat membuka dan menambah wawasan para peserta. Ekstrak daun nangka yang diperoleh melalui metode maserasi diidentifikasi metabolit sekundernya melalui skrining fitokimia. Ekstrak kemudian akan diformulasikan menjadi sediaan masker yang akan melembabkan kulit.

\section{b. Evaluasi dan Tindak Lanjut}

Aktivitas daun nangka sebagai pelembab kulit dibuktikan dengan uji homogenitas, uji $\mathrm{pH}$, uji organoleptis serta uji kelembaban yang akan dilibatkan seluruh peserta yang mengikuti kegiatan ini. Hasil seluruh pengujian sudah disesuaikan dengan referensi yang tersedia. Proses pengamatan hasil dilakukan beberapa hari setelah kegiatan seminar ini.

\section{Hasil dan Pembahasan Hasil Ekstrak Daun Nangka}

Hasil yang didapat dari proses ekstrak dari $500 \mathrm{~g}$ daun nangka etanol $96 \%$ yang dipekatkan dengan rotary evaporator pada suhu $\pm 80^{\circ} \mathrm{C}$ yaitu berupa $100 \mathrm{ml}$. Etanol yang digunakan adalah etanol $96 \%$ yang lazim digunakan untuk ekstraksi sampel yang segar.

Penentuan golongan dilakukan untuk mengetahui kandungan senyawa metabolit sekunder Adapun skrining fitokimia dari ekstrak etanol daun nangka dapat dilihat pada tabel 1 . dibawah ini.

Tabel 1. Hasil skrining fitokimia ekstrak etanol daun nangka

\begin{tabular}{ccc}
\hline Sampel & $\begin{array}{c}\text { Uji Skrining } \\
\text { Fitokimia }\end{array}$ & Hasil \\
\hline $\begin{array}{c}\text { Ekstrak } \\
\text { etanol daun } \\
\text { nangka }\end{array}$ & Flavonoid & $(+)$ \\
\hline
\end{tabular}

\section{Hasil Uji Homogenitas}

Hasil uji homogenitas formulasi sediaan krim masker ekstrak etanol daun nangka (Atrocarpus Heterophyylu lam.) dapat dinyatakan lulus uji homogenitas dikarenakan tidak terdapat adanya butiran-butiran kasar pada sediaan. Pada blanko dan konsentrasi $5 \%$ dan $10 \%$ hasil uji homogenitas formulasi sediaan krim masker ekstrak etanol daun nangka (Atrocarpus Heterophyylu lam.) dapat dilihat pada tabel 2 .

Tabel 2. Hasil uji Homogen

\begin{tabular}{c|c}
\hline Formula & Uji Homogenitas \\
\hline F1 & Homogen \\
\hline F2 & Homogen \\
\hline F3 & Homogen \\
\hline
\end{tabular}

Berdasarkan hasil seminar diatas tabel 2. sediaan krim masker ekstrak daun nangka pada konsentrasi $5 \%$, $10 \%$ dan blanko dinyatakan lulus uji homogenitas.

Uji homogenitas yang tidak terdapat butiran-butiran kasar yang 
Received: 14 June 2021 :: Accepted: 21 June 2021 :: Published: 30 June 2021

terdapat pada sediaan krim masker ekstrak etanol daun nangka sebagai pelembab kulit wajah.

\section{Hasil Uji pH Sediaan}

Hasil uji pH menunjukkan hasil pemeriksaan dari kedua formulasi sediaan krim masker. Adapun rengtang $\mathrm{pH}$ dapat dlihat pada tabel 3 dibawah ini.

Tabel 3 Hasil Uji pH Sediaan

\begin{tabular}{cc}
\hline Sediaan & Nilai $\mathrm{pH}$ \\
\hline F1 & 6,5 \\
\hline F2 & 6,7 \\
\hline F3 & 6,3
\end{tabular}

Berdasarkan data tabel 3 menunjukkan hasil pemeriksaan uji $\mathrm{pH}$ dari kedua sediaan krim masker. $\mathrm{pH}$ untuk sediaan krim pada kulit adalah 68 , dengan begitu sediaan aman untuk digunakan.

\section{Hasil Uji Organoleptis}

Semakin besar jumlah konsenstrasi masker krim dalam formula akan memberikan konsisten mempengaruhi sedikit perubahan warna. Hasil uji organoleptis dapat dilihat pada tabel 4 di bawah ini.

Tabel 4 Hasil Uji Organoleptis

\begin{tabular}{|c|c|c|c|}
\hline \multirow[b]{2}{*}{ Formula } & \multicolumn{2}{|c|}{ Organoleptis } & \multirow[b]{2}{*}{ Aroma } \\
\hline & Bentuk & Warna & \\
\hline $\mathrm{F} 1$ & $\begin{array}{l}\text { Semi } \\
\text { Padat }\end{array}$ & Hijau & Mawar \\
\hline F2 & $\begin{array}{l}\text { Semi } \\
\text { Padat }\end{array}$ & $\begin{array}{l}\text { Hijau } \\
\text { pekat }\end{array}$ & Mawar \\
\hline F3 & $\begin{array}{l}\text { Semi } \\
\text { Padat }\end{array}$ & Putih & Mawar \\
\hline
\end{tabular}

Pengamatan organoleptis ekstrak bertujuan sebagai pengenalan awal panca indra dengan mendeskripsikan bentuk, bau, dan rasa. Hasil pengamatan organoleptis terlihat pada tabel 4 terjadinya perubahan warna pada konsentrasi $5 \%$ yaitu perubahan warna hijau dan pada konsentrasi $10 \%$ yaitu perubahan warna hijau pekat.

Menurut asumsi seminarsediaan krim masker ekstrak etanol daun nangka pada konsentrasi $5 \%$ dapat terjadi perubahan warna dari hijau berubah menjadi hijau keputihan.

\section{Hasil Uji Kelembapan}

Pengujian kemampuan sediaan untuk melembabkan kulit dilakukan pada 6 orang responden dengan menggunakan alat Skin Analyzer dengan mengukur persen kelembapanulit setelah menggunkan sediaan krim pelembab dari ekstrak daun nangka berbagai konsentrasi dan blanko. Hasil uji kelembapan dapat dilihat pada tabel 5 dibawah ini.

Tabel 5. Data pengukuran kelembapan kulit setelah pengolesan sediaan

\begin{tabular}{|c|c|c|c|}
\hline \multirow{2}{*}{$\begin{array}{l}\text { Kelomp } \\
\text { ok }\end{array}$} & \multicolumn{3}{|c|}{$\begin{array}{c}\text { Intervensi Terhadap } \\
\text { Responden }\end{array}$} \\
\hline & Responden & $\begin{array}{c}\text { Sebelu } \\
\mathrm{m}\end{array}$ & $\begin{array}{c}\text { Setela } \\
\mathrm{h}\end{array}$ \\
\hline \multirow{4}{*}{$\begin{array}{c}\text { Krim } \\
\text { Pelemba } \\
\text { b } \\
\text { ekstrak } \\
\text { daun } \\
\text { nangka } \\
5 \%\end{array}$} & $\begin{array}{l}\text { Responden } \\
\text { I }\end{array}$ & 27,7 & 31,5 \\
\hline & $\begin{array}{c}\text { Responden } \\
\text { II } \\
\end{array}$ & 28,1 & 31,1 \\
\hline & $\begin{array}{l}\text { Responden } \\
\text { III }\end{array}$ & 28,8 & 32,7 \\
\hline & Rata - rata & 29,0 & 32,5 \\
\hline \multirow{6}{*}{$\begin{array}{c}\text { Krim } \\
\text { Pelemba } \\
\text { b } \\
\text { ekstrak } \\
\text { daun } \\
\text { nangka } \\
10 \% \\
\end{array}$} & $\begin{array}{c}\text { Responden } \\
\text { I }\end{array}$ & 28,3 & 31,4 \\
\hline & $\begin{array}{c}\text { Responden } \\
\text { II } \\
\end{array}$ & 26,7 & 32,3 \\
\hline & $\begin{array}{l}\text { Responden } \\
\text { III }\end{array}$ & 27,1 & 32,7 \\
\hline & \multicolumn{3}{|c|}{28,5} \\
\hline & Rata - rata & & $\begin{array}{l}3 \\
3\end{array}$ \\
\hline & \multicolumn{3}{|c|}{ Jumlah $=3$ orang $\times 2$ kelompok } \\
\hline
\end{tabular}

Berdasarkan tabel 5 diatas dapat dilihat bahwa semakin tinggi konsentrasi ekstrak daun nangka yang ditambahkan pada sediaan krim, maka semakin tinggi pula kemampuan untuk melembabkan kulit, hal ini terlihat pada formula 2 dengan konsentrasi 10\% yang lebih banyak mengandung ekstrak daun nangka, dimana ekstrak daun nangka berfungsi untuk 
Received: 14 June 2021 :: Accepted: 21 June 2021 :: Published: 30 June 2021

melembabkan kulit. Berdasarkan hasil uji. Kelembaban diketahui bahwa sediaan ekstrak daun nangka dengan konsentrasi 5\% dan 10\% memberi efek melembabkan kulit.

Menurut refrensi dari alat Skin Moisture Analyzer, kriteria kelembaban kulit adalah jika lebih kecil dari 30\% kurang lembab, 30-50\% lembab, dan lebih besar dari $50 \%$ sangat lembab. Berarti semua formula dapat melembabkan kulit dengan kategori lembab.

Hasil yang diperoleh dari kegiatan pengabdian ini adalah sebagai berikut:

1. Materi seminar dapat dipahami oleh peserta seminar yang dibuktikan melalui pre test dan post test yang diberikan.

2. Peserta seminar dapat menerapkan prosedur uji kelembapan dari sediaan terhadap ekstrak daun nangka. Hal ini dapat diketahui melalui interaksi dan keterlibatan peserta dalam melakukan uji kelembapan.

3. Peserta seminar mendapat pengetahuan baru mengenai manfaat dari beberapa tanaman hias yang dapat dijadikan sebagai tanaman obat atau sebagai kosmetik.

\section{Kesimpulan}

Hasil seminar yang dillakukan terhadapdaun nangka diperoleh kesimpulan sebagai berikut:

1. Ekstrak daun nangka dapat diformulasikan kedalam sediaan krim masker dan memenuhi kriteria karakteristik.

2. Sediaan krim masker ekstrak daun nangka mempunyai kemampuan untuk melembabkan kulit dan yang paling besar diperoleh pada konsentrasi $10 \%$ dengan kelembaban 33,3 dapat melembabkan kulit dan pada konsentrasi $5 \%$ dengan kelembaban 32,5 juga dapat melembabkan kulit tetapi tingkat kelembaban yang sedang.

\section{Ucapan Terima Kasih}

Pengabdi menyampaikan ucapan terima kasih kepada:

a. Lembaga Seminardan Pengabdian Kepada Masyarakat (LPPM) Institut Kesehatan Medistra Lubuk Pakam

b. Direktur Rumah Sakit Granmed Lubuk Pakam

\section{Daftar Pustaka}

Andhi, F. Hafrizal, R. (2020). Karakterisasi Ekstrak Etanol Buah Citrus amblycarpa (L), Citrus aurantifolia (S.), dan Citrus sinensis (O.) Jurnal Farmasi Dan Ilmu Kefarmasian Indonesia. Vol.7 No. 2. http://dx.doi.org/10.20473/jfiki.v7i22 020.100-113

Diah, P. (2016). Pengaruh Pemberian Ekstrak Etanol Daun Nangka (Artocarpus heterophyllus Lamk) terhadap penurunan volume udema pada kaki tikus. Fakultas Farmasi Universitas Setia Budi Surakarta.

Hernani. (2011). Pengembangan Biofarmaka sebagai Obat Herbal untuk Kesehatan. Buletin Teknologi Pascapanen Pertanian: Bogor Agricultural University.

Maharani, A. (2015). Penyakit Kulit Perawatan, Pencegahan dan Pengobatan. Yogyakarta: Pustaka Baru Press.

Sukmawati, A. (2013). Pengaruh Konsentrasi PVA, HPMC, dan Gliserin Terhadap Sifat Fisik Masker Wajah Gel Peel Off Ekstrak Etanol 96\% Kulit Buah Manggis. Skripsi. Jurusan Farmasi Universitas Udayana, Bali.

Wibisana, R. (2013). Meraup Uang dari Bisnis Olahan Pisang. Skripsi. Yogyakarta: Sakti. 